\title{
MENAKAR PRO-KONTRA HUKUM UJRAH PENGAJAR ILMU AGAMA DAN URGENSINYA DALAM KONTEKS ERA MODERN
}

\author{
SAMHERI \\ STIU Al-Mujtama Pamekasan \\ e-mail: samheri.msh@gmail.com
}

\begin{abstract}
Abstrak: Penulisan karya ilmiah ini didasarkan pada kontroversi hukum upah bagi para pengajar keagamaan Islam yang terjadi di masyarakat yang sering dijadikan alasan masyarakat saling mencemooh yang satu dengan lainnya, dengan alasan berdakwah atau mengajar agama Islam tidak ikhlas dan materialistik. padahal orang yang dicemooh juga memiliki alasan dan dalil yang sah dalam mengerjakan dakwah dan pengajaran mereka dengan mengambil upah dari dakwah atau pengajarannya itu. Penelitian in Penelitian ini menggunakan jenis penelitian library research yang difokuskan pada data tertulis dengan mengajukan rumusan masalah bagaimankah urgensi upah terhadap pengajar ilmu agama dan konsekuensinya dalam kehidupan sehari-hari, dan bagaimana hukum menerima upah bagi pengajar ilmu agama. Hasil penelitian ini adalah pemberian upah adalah wajib apabila pekerjaannya hanyalah mengajar agama (dijadikan profesinya). Mengingat mengajar agama adalah satu kewajiban dari orang yang mengetahui terhadap orang tidak mengetahui. Ulama fikih beda pendapat terhadap hukum upah pengajar keagamaan Islam ini, ada yang membolehkan dan ada yang tidak membolehkan. Namun demikian, menerima upah dalam mengajarkan al-Qur'an pada saat ini sudah dianggap wajar, karena selama ini relatif tidak ada keluhan dari masyarakat untuk menyisihkan sebagian hartanya untuk upah itu.
\end{abstract}

Kata kunci: Kontroversi, Hukum, Upah (Ujrah), Urgensi, Ulama

\begin{abstract}
This research is based on the legal controversy of wages for Islamic religious teachers that occur in society which is often used as a reason for people to ridicule one another with reasons for preaching and or teaching Islam not sincerely and materialistically. Even though people who are mocked also have legitimate reasons and arguments in doing their dakwah and teaching by taking wages from their dakwah
\end{abstract}

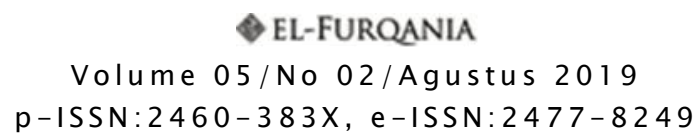


or teaching. This research is librabry research which focus on the written data with research focus is how important wages for islamic religious teachers and its consequences in daily life, then how about the legal law in recieving a wage for islamic religous teachers. The result of this research is giving a wages is mandatory if islamic teacher's job is just as a Islamic religious teacher (no job else). Beacause of teaching the religous subject is an obligation for all of people who knows about religous knowladge. Islamic law scholars' opinions are different about this issue. According to one of them giving wages is legal, and others stated illegal, but however giving wages for the Islamic teachers is reasonable or permitted. Because all this time there is no complain from the society to give wages for Islamic religious teachers.

Keyword: Legal, Controvercy, Wages (Ujrah), Urgency, Islamic Religious Teachers.

\section{Prolog}

Pemberian imbalan dalam aktifitas dakwah sebenarnya bukanlah fenomena baru, sudah banyak terjadi dan sudah berlangsung lama bahkan fenomena ini terjadi hampir di semua elemen masyarakat dan aktifitas keagamaan, baik itu aktifitas dakwah maupun aktifitas lain yang berhubungan dengan keagamaan. Hal ini sangat tampak dalam fenomena pengisian ceramah agama, baik itu dalam forum akademik maupun dalam forum ceramah agama umum di masyarakat, di dalamnya dapat ditemui banyak terjadi aktifitas pemberian imbalan dari panitia acara kepada tokoh Agama, ustadz, ustadzah yang mengisi ceramah tersebut.

Para ulama berbeda pendapat mengenai upah atas praktik ibadah. Membayar jasa atas praktik ibadah seperti menyewa orang lain untuk șalat, puasa, melaksanakan ibadah haji, membaca alQur'an yang pahalanya dihadiahkan kepada orang yang menyewa, adzan, imam solat, dll., itu hukumnya tidak boleh. ${ }^{2}$ hal itu sesuai dengan sabda Nabi saw. sebagaimana berikut:

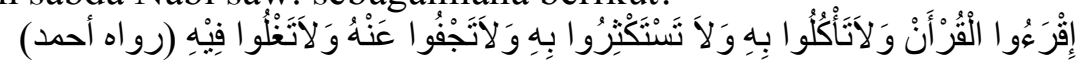

\footnotetext{
${ }^{1}$ Moh Aqim Askhabi, "Pemberian Imbalan dalam Aktifitas Dakwah Agama Islam", Journal Fisip Unair, vol. 4, No. 2, (Februari, 2015), i

${ }^{2}$ Syekh Sulaiman Ahmad Yahya al-Faifi, Ringkasan Fiqih Sunnah Sayyid Sabiq, Terj, Ahmad Tirmidzi dkk, (Jakarta: Pustaka Al-Kautsar, 2013), 804-805.
} 
'Bacalah al-Qur'an dan jangan kamu berlebih-lebihan, jangan kamu berat-beratkan, jangan kamu makan dengannya dan jangan kamu mencari kekayaan dengannya"3

Dalam fakta sejarah membuktikan bahwa para ulama berbeda sikapnya terhadap penyediaan fasilitas finansial tersebut. Michael Chamberlain, seorang sejarawan sosial dari Universitas Wisconsin, menemukan bukti-bukti sejarah yang menunjukkan bahwa ulamaulama ternama di kota Damaskus (1190-1350) menolak pemberian finansial itu dan menganggapnya sebagai bentuk perilaku korup. Ulama yang bersikap demikian ini pada umumnya memperoleh penghargaan dan penghormatan yang tinggi, baik dari para pelajar maupun dari kalangan ulama sendiri. Namun demikian, tidak sedikit pula ulama yang berada di kota Damaskus tersebut yang memanfaatkan reputasi mereka untuk memperoleh fasilitas finansial dari berbagai lembaga pendidikan, dan tidak banyak bukti yang menjelaskan bahwa penerimaan fasilitas finansial itu bisa mencoreng reputasi mereka. ${ }^{4}$

Adapun alasan dan dalil yang dipegangteguh oleh ulama yang tidak mengambil upah finansial diantaranya adalah surat Yāsin ayat 21 yang bermaksud "Ikutilah orang yang tiada minta balasan kepadamu; dan mereka adalah orang-orang yang mendapat petunjuk." (QS. Yāsin [36] : 21). ${ }^{5}$

Kata (اتبعوا) ini mengukuhkan makna lafaz yang sama pada ayat sebelumnya (orang yang tiada minta balasan kepada kalian) atas misi (risalah) yang disampaikannya itu (dan mereka adalah orangorang yang mendapat petunjuk) lalu dikatakan kepadanya, "Kamu seagama dengan mereka."

Namun untuk mengajar hal yang berbau agama, pada saat ini para fuqaha' menyatakan bahwa boleh mengambil upah dari pengajaran al-Qur'an dan ilmu-ilmu syariah lainnya, karena para guru

${ }^{3}$ Nazih Ahmad, Qạ̣āyā Fiqhiyyah Mu'āsirah fî al-Māl wa al-Iqtiṣād, (Damaskus: Dar al-Qalam. 2001), 298.

${ }^{4}$ Michael Chamberlain, "Knowledge and Social Practice In "Medieval Damascus", Dinamika, Vol. 15, No. 1, (Juli 2015),83.

5 Kemenag RI, Qur'an Asy-syifaa' Hafalan dan Tajwid Berwarna, (Bandung: Sygma Creative Media, 2018), 441.

${ }^{6}$ Jalaluddin al-Mahalli dan Jalaluddin al-Suyuți, Tafsir al-Qur'an al-Azīm li Imām al-Jalālain, (t.t.: cv. Pustaka, t.th), 124. 
membutuhkan penunjang kehidupan mereka dan kehidupan orangorang yang berada dalam tanggungan mereka. Dan waktu mereka juga tersita untuk kepentingan pengajaran al-Qur'an dan ilmu-ilmu syariah tersebut, maka dari itu diperbolehkan memberikan kepada mereka sesuatu imbalan dari pengajaran ini. ${ }^{7}$ Setiap orang berhak mendapatkan kesejahteraan. Islam menetapkan dua jalan untuk memenuhi semua kebutuhan. Yakni pemenuhan kebutuhan sandang, pangan dan papan, dibebankan kepada setiap individu dalam masyarakat, baik dipenuhi langsung atau melalui ayah, wali dan ahli waris. ${ }^{8}$

Bahkan patut untuk memberi lebih sesuai dengan tenaga mengajarnya. Pandangan lama menyatakan bahwa kenaikan imbalan (gaji/upah) secara otomatis akan dibarengi dengan kenaikan etos kertas, kreatifitas dan produktivitasnya. ${ }^{9}$

berdasarkan paparan data di atas, penulis akan membahas mengenai urgensi upah terhadap pengajar ilmu agama dan konsekuensinya dalam kehidupan sehari-hari, dan bagaimana hukum menerima upah bagi pengajar ilmu agama.

\section{Pengertian Ujrah (Upah)}

Dalam Kamus Istilah Ekonomi, Keuangan dan Bisnis Syari'ah $A-Z$, kata ujrah berartikan upah untuk kerja. ${ }^{10}$ Secara etimologi, kata upah disamakan dengan kata al-ujrah dalam Bahasa Arab. ${ }^{11}$ Jadi, upah ialah mengacu pada penghasilan pada tenaga kerja. ${ }^{12}$ Secara terminologi ujrah adalah memberikan sesuatu, baik berupa uang atau barang kepada seseorang sebagai ganti atas jasa mengerjakan

\footnotetext{
${ }^{7}$ Sayyid Sabiq, Fiqh al-Sunnah, Terj, Nor Hasanudin, (Jakarta: Pena Pundi Aksara, 2006), 22.

${ }^{8}$ Fuad Riyadi, "Sistem Dan Strategi Pengupahan Perspektif Islam”, Jurnal Iqtishadia, Vol. 8, No. 1,(Maret, 2015), 183.

${ }^{9}$ Moekijat, Administrasi Gaji Dan Upah, (Bandung: Mandar Maju, 1992), 7.

${ }^{10}$ Muhammad Sholahuddin, Kamus Istilah Ekonomi, Keuangan, dan Bisnis Syariah $A-Z$, (Jakarta: PT Gramedia Pustaka Utama, 2011), 183.

11 Ahmad Warson Munawwir, Kamus Al-Munawwir, (Surabaya: Penerbit Pustaka Progresif, 1997), 9.

12 M. Abdul Mannan, Teori dan Praktek Ekonomi Islam, (Yogyakarta: PT. Dana Bhakti Prima Yasa, 1997), 116.
} 
pekerjaan tertentu dengan batas waktu tertentu sesuai dengan kesepakatan kedua belah pihak. ${ }^{13}$

Upah dalam Islam masuk juga dalam bab ijärah sebagaimana perjanjian kerja, menurut bahasa ijarah berarti "upah" atau "ganti" atau imbalan, karena itu lafaz ijarah mempunyai pengertian umum yang meliputi upah atas pemanfaatan sesuatu benda atau imbalan sesuatu kegiatan atau upah karena melakukan sesuatu aktifitas. ${ }^{14}$

Berdasarkan pengertian di atas untuk ijarah sama halnya dengan ujrah karena ujrah pada hakikatnya adalah bagian dari akad ijärah. Sedangkan upah (fee) atau imbalan merupakan nama lain dari ujrah atau arti dari ujrah itu sendiri, dimana upah atau imbalan sering digunakan oleh masyarakat awam yang tidak mengetahui istilahistilah di dalam perbankan.

Disyaratkan, besar kecilnya upah itu harus ditentukan (diketahui sebelumnya) sama dengan besar kecilnya uang sewa juga harus ditentukan sebelumnya. ${ }^{15}$ Dan Islam telah menetapkan aturan untuk pemberian imbalan (upah) sebagai bagian dari rezeki yang telah Allah tetapkan itu. Hal ini didasarkan pada hadith Rasulullah SAW berikut: "Barangsiapa yang kami angkat menjadi pegawai atau karyawan untuk mengerjakan sesuatu, kemudian kami beri dia upah yang semestinya (pantas, ditambah dengan tunjangan-tunjangannya), tetapi dia megambil lebih (banyak) dari upah yang semestinya berarti dia telah (melakukan) korupsi (ghulūl)." (HR. Abu Dawud). ${ }^{16}$

Islam tidak membatasi cara-cara tertentu bagi pemberian upah, karena upah tersebut berbeda-beda menurut situasi, dan dipengaruhi oleh banyak faktor, di antaranya adalah jenis pekerjaan, waktu yang diperlukan, harga barang yang diproduksi dan taraf hidup. Para ahli hukum Islam menyesuaikan faktor-faktor ini dengan upah yang setimpal (Ujrah al-Mithil) yaitu upah yang sepadan dengan kerjanya serta sepadan dengan jenis pekerjaannya sesuai dengan jumlah nilai yang disebutkan dan disepakati oleh kedua belah pihak

${ }^{13}$ Muhammad Syafii Antonio, Bank Syariah dari Teori ke Praktik, (Jakarta: Gema Insani Pers, 2001), 117.

${ }^{14}$ Helmi Karim, Fiqih Muamalah, (Jakarta: Salemba Empat, 2001), 30.

${ }^{15}$ Imam Taqiyuddin Abu Bakar al-Husaini, Terjemahan Kifayatul Akhyar, Jil. II, Terj, Achmad Zainuddin dan A. Ma'ruf Asrori, (Surabaya: PT Bina Ilmu, 2011), 196.

${ }^{16}$ Yan Orgianus, Moralitas Islam dalam Ekonomi dan Bisnis, (Bandung: Penerbit Marja, 2012), 69. 
yaitu pemberi kerja dan penerima kerja pada saat transaksi pembelian jasa. Berdasarkan hal tersebut Fuqaha' mensyaratkan agar upah dalam melakukan sesuatu pekerjaan harus ditentukan, mereka menetapkan harus dibayarkannya upah pada saat habisnya masa kontrak. $^{17}$

Apabila tidak ada kesepakatan diantara mereka mengenai kapan harus membayar upah, maka upah tersebut dapat dibayar kapan saja. Namun yang utama adalah upah dibayar sebelum kering keringatnya, sebagaimana hadith Nabi.

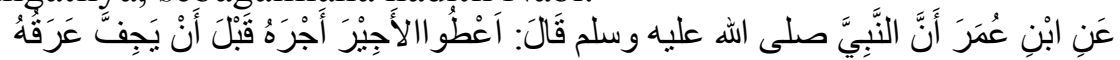

"Dari Ibnu Umar bahwa Rasulullah bersabda, "Berikanlah upah pekerja sebelum keringatnya kering. "(HR. Ibnu Majah). ${ }^{18}$

Jika waktu upah tersebut sudah ditentukan, maka harus dipenuhi apabila waktunya telah selesai. Sedangkan apabila akad tersebut berlangsung atas suatu pekerjaan, maka upahnya harus diberikan apabila pekerjaan itu selesai dilaksanakannya. ${ }^{19}$ Berbeda dengan upah dalam ijarah yang fäsid menurut ijmak, upah dalam ijärah yang fäsid tidak wajib karena akad, tetapi wajib sebab pemenuhan manfaat. ${ }^{20}$

Sedangkan menyangkut penentuan upah kerja, syari'at Islam tidak memberikan ketentuan yang rinci secara tekstual, baik dalam ketentuan al-Qur'an maupun Sunnah Rasul, secara umum, ketentuan al-Qur'an yang ada kaitannya dengan penentuan upah kerja adalah, "Sesungguhnya Allah menyuruh (kamu) berlaku adil dan berbuat kebajikan, memberi kepada kaum kerabat, dan Allah melarang dari perbuatan keji, kemungkaran dan permusuhan. Dia memberi pengajaran kepadamu agar kamu dapat mengambil pelajaran." (QS. Al-Nahl [16]: 90).

Apabila ayat itu dikaitkan dengan perjanjian kerja, maka dapat dikemukakan bahwa Allah memerintahkan pada para pemberi

17 Ahmad Muhammad al-'Assal dan Fathi Ahmad Abdul Karim, Sistem, Prinsip dan Tujuan Ekonomi Islam, Terj, Imam Saefudin, (Bandung: CV Pustaka Setia, 1999), 168.

${ }^{18}$ Ibnu Majah, Sunan Ibnu Majah, Jil. II, Terj, Muhammad Nashiruddin al-Albani, (Jakarta: Pustaka Azzam, 2007), 303.

19 Abdul Aziz Dahlan DKK, Ensiklopedi Tematis Dunia Islam Ajaran, (Jakarta, PT Ichtiar Baru Van Hoeve, $\mathrm{tt}$ ), 157.

${ }^{20}$ Sa'di Abu Habieb, Ensiklopedi Ijmak Persepakatan Ulama' dalam Hukum Islam, Terj, Sahul Machfudz dan Mustofa Bisri, (Jakarta: Pustaka Firdaus, 1987), 761. 
pekerjaan (majikan) untuk berlaku adil, berbuat baik, dan dermawan kepada para pekerjanya. Kata "kerabat" dalam ayat itu, dapat diartikan "tenaga kerja", sebab para pekerja tersebut sudah merupakan bagian dari perusahaan, dan kalau bukan karena jerih payah pekerja tidak mungkin usaha si majikan dapat berhasil. ${ }^{21}$

Upah ini diperlukan karena pekerjaan yang mesti dilakukan oleh seseorang itu banyak dan andaikata semua itu mesti dikerjakan oleh dirinya sendiri, tentulah banyak waktu yang disia-siakan. Oleh karena itu, mengupah orang lain untuk melakukan sebahagian pekerjaannya membolehkan banyak pekerjaan yang penting dapat dilaksanakannya. ${ }^{22}$ Disebabkan pekerja mempunyai andil yang besar untuk kesuksesan usaha majikan, maka majikan berkewajiban untuk mensejahterakan para pekerjanya, termasuk dalam hal ini memberikan upah yang layak. ${ }^{23}$

Dalam salah satu hadith dijelaskan, yang mana artinya ialah: "Dari Ibnu Umar bahwa Rasulullah bersabda, "Berikanlah upah pekerja sebelum keringatnya kering." (HR Ibnu Majah). ${ }^{24}$ Dengan demikian, bisa dilihat bahwasanya tidak ada larangan dalam upah sebagaimana yang dijelaskan dalam Hadith Nabi yang berbunyi:

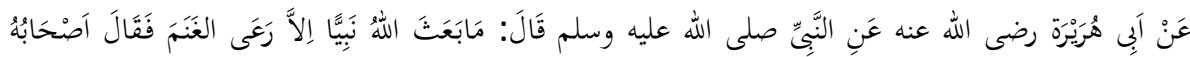

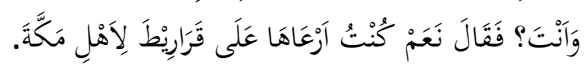

Artinya: "Dari Abu Hurairah ra. dari Nabi SAW bersabda: "Tidaklah Allah Membangkitkan seorang Nabi melainkan ia seorang yang mengembalakan kambing". Para sahabat beliau bertanya: "dan engkau?" Beliau bersabda: "ya, aku mengembalakannya atas (upah) seqirat-seqirat milik penghuni Mekkah. ${ }^{\text {,25 }}$

21 Suhrawardi K. Lubis dan Farid Wajdi, Hukum Ekonomi Islam, (Jakarta: Sinar Grafika, 2012), 167.

22 Imam Al-Ghazali, Ihya' Ulumuddin Hak Milik Muslim, (Selangor: Illusion Network, 2013), 803.

23 Suhrawardi K. Lubis dan Farid Wajdi, Hukum Ekonomi Islam, (Jakarta: Sinar Grafika, 2012), 167.

${ }^{24}$ Muhammad Syafii Antonio, Bank Syariah dari Teori ke Praktik, (Jakarta: Gema Insani, 2001), 117-118.

25 Zaenuddin Ahmad Azzubaidi, Terjemah Hadits Shahih Bukhari, Terj, Muhammad Zuhri, (Semarang: CV. Toha Putra, 1986), 698. 
Sedangkan hukum asal dalam upah pekerja di lembaga negara adalah tidak kurang dari kadar secukupannya. ${ }^{26}$

Adapun hak mendapat upah pemberi sewa, baik objek sewanya berupa barang maupun tenaga atau jasa, bisa meminta upah dalam beberapa keadaaan berikut ini:

1. Ketika pekerjaan telah selesai. Diriwayatkan dari Ibnu Majah bahwa "Berikanlah upah kepada pekerja sebelum keringatnya mengering"

2. Objek sewa telah benar-benar diambil manfaatnya, jika objek sewanya berupa barang atau benda.

3. Objek sewa sudah memungkinkan untuk bisa diambil manfaatnya, yaitu ketika masa sewa sudah dianggap cukup bagi si penyewa untuk memanfaatkan objek sewanya meskipun faktanya belum dilakukan.

4. Membayarkan upah di muka, atau ketika menjadi kesepakatan pembayaran upah di muka oleh kedua pelaku transaksi ijarah. ${ }^{27}$

\section{Jenis-jenis Ujrah (Upah)}

1. Upah yang Sepadan (Ujrah al-Mithli)

Ujrah al-Mithli adalah upah yang sepadan dengan kerjanya serta sepadan dengan jenis pekerjaannya sesuai dengan jumlah nilai yang disebutkan dan disepakati oleh kedua belah pihak yaitu pemberi kerja dan penerima kerja pada saat transaksi pembelian jasa. Oleh karena itu, dalam menentukan tarif upah atas kedua belah pihak yang melakukan transaksi pembeli jasa, mereka harus menentukan upah yang wajar sesuai dengan pekerjaanya atau upah yang dalam situasi normal bisa diberlakukan dan sepadan dengan tingkat jenis pekerjaan tersebut. $^{28}$

Tujuan ditentukannya tarif upah yang sepadan adalah untuk menjaga kepentingan kedua belah pihak dan menghindarkan adanya unsur eksploitasi di dalam transaksi. Dengan demikian, melalui tarif

${ }^{26}$ Jabirah bin Ahmad al-Harithī, Fikih Ekonomi Umar bin al-Khatab, Terj, Asmuni Solihin Zamakhsyari, (Jakarta: Pustaka al-Kautsar, 2014), 238.

${ }^{27}$ Syaikh Sulaiman Ahmad Yahya al-Faifi, Ringkasan Fikih Sunnah Sayyid Sabiq, Terj, Ahmad Tirmidzi dkk, (Jakarta: Pustaka al-Kautsar, 2014), 806-807.

28 Arskal Salim, Etika Intervensi Negara: Perspektif Etika Politik Ibnu Taimiyah, (Jakarta: Logos, 1999), 99. 
upah yang sepadan, setiap perselisihan yang terjadi dalam transaksi jual beli jasa akan dapat terselesaikan secara adil. ${ }^{29}$

\section{Upah yang telah disebutkan (Ujrah al-Musammā)}

Upah yang disebut ujrah al-musammā syaratnya ketika disebutkan harus disertai adanya kerelaan kedua belah pihak yang sedang melakukan transaksi terhadap upah tersebut. Dengan demikian, pihak musta'jir tidak boleh dipaksa untuk membayar lebih besar dari apa yang telah disebutkan, sebagaimana pihak mu'jir juga tidak boleh dipaksa untuk mendapatkan lebih kecil dari apa yang telah disebutkan. Dengan kata lain, wajib mengikuti ketentuan syara'.

Apabila upah tersebut disebutkan pada saat melakukan transaksi, maka upah tersebut merupakan upah yang disebutkan (ajrun musammāa). Apabila belum disebutkan atau terjadi perselisihan upah yang telah disebutkan, maka upahnya bisa berlaku upah yang sepadan (ajrun mithli). ${ }^{30}$

\section{Rukun dan Syarat Ujrah (Upah)}

1. Rukun Ujrah adalah sebagai berikut:

a. Mu'jir dan musta'jir yaitu pihak yang melakukan akad ujrah. Mu'jir adalah orang yang memberikan upah dan musta'jir adalah orang yang menerima upah untuk melakukan sesuatu.

b. Sighat (akad). Syarat ijab-qabul antara Mu'jir dan musta'jir sama dengan ijab-qabul yang dilakukan dalam jual beli.

c. Ujrah (upah). Dasar yang digunakan untuk penetapan upah adalah besarnya manfaat yang diberikan oleh pekerja tersebut. Bukan didasarkan pada taraf hidup, kebutuhan fisik minimum ataupun harga barang yang dihasilkan. Upah yang diterima dari jasa yang haram, menjadi rezeki yang haram.

d. Ma'qüd alaih (barang yang menjadi Obyek). Sesuatu yang dikerjakan dalam upah mengupah, disyaratkan pada pekerjaan yang dikerjakan dengan beberapa syarat. Adapun salah satu syarat terpenting dalam transaksi ini adalah bahwa jasa yang diberikan adalah jasa yang halal. Dilarang memberikan jasa

\footnotetext{
${ }^{29}$ Ibid, 100.

30 Taqyuddin an-Nabhani, Membangun Sistem Ekonomi Alternatif Perspektif Islam, (Surabaya: Risalah Gusti, 1996), 103.
} 
yang haram seperti keahlian membuat minuman keras atau membuat iklan miras dan sebagainya. Asal pekerjaan yang dilakukan itu dibolehkan Islam dan akad atau transaksinya berjalan sesuai aturan Islam. Bila pekerjaan itu haram, sekalipun dilakukan oleh orang non muslim juga tetap tidak diperbolehkan. ${ }^{31}$

2. Syarat Ujrah (upah) adalah sebagai berikut:

a. Hendaknya harta tersebut harta yang bernilai dan diketahui. Syarat ini disepakati oleh para ulama, maksud syarat ini sudah dijelaskan dalam pembahasan akad jual beli. Landasan hukum disyaratkan mengetahui upah adalah sabda Rasulullah:

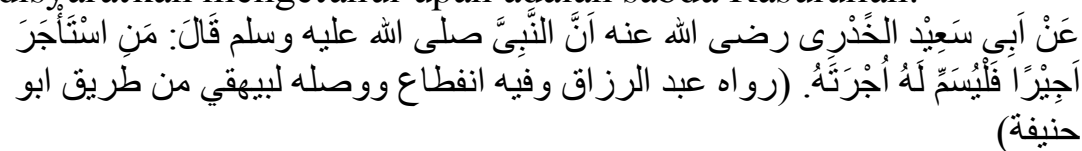

Dari Abū Sa'ìd ra. (katanya): Sesungguhnya Nabi SAW. bersabda: "Barangsiapa mengupah seorang buruh/pekerja maka hendaklah dia menyebut/tetapkan upahnya kepadanya." Diriwayatkan oleh Abdu al-Razzāq, tetapi dalam sanadnya ada yang terputus. Al-Baihaqi menyambung sanadnya dari Abu Hanifah. ${ }^{32}$

Mengetahui upah, tidak sah kecuali dengan isyarat dan penentuan, ataupun dengan penjelasan. Menurut Abū Hanifah, diharuskan mengetahui pelunasan upah jika upah itu termasuk barang yang perlu dibawa dan membutuhkan biaya. Sedang menurut al-Șāhibān, hal itu tidak disyaratkan dan tempat akad cukup dijadikan tempat untuk pelunasan. ${ }^{33}$

b. Upah tidak berbentuk manfaat yang sejenis dengan ma'qüd 'alaih (Objek Akad).

Upah tidak berbentuk manfaat yang sejenis dengan ma'qūd 'alaih (objek akad). Misalkan, Ijärah tempat tinggal dibayar dengan tempat tinggal, jasa dibayar dengan jasa, penunggangan dibayar dengan penunggangan, dan pertanian dibayar dengan pertanian. Syarat ini menurut Madhhab Malikiyah adalah

${ }^{31}$ Qomarul Huda, Fiqh Muamalah, (Yogyakarta: Sukses Offset, 2011), 80.

${ }^{32}$ Abu Bakar Muhammad, Terjemahan Subulus Salam, (Surabaya: al-Ikhlas, 1991), 293.

33 Wahbah al-Zuhaili, Fiqih Islam Wa Adillatuhu, Terj, Abdul Hayyie al-Kattani, dkk,(Depok: Gema Insani, 2011),400. 
cabang dari riba. Mereka menganggap bahwa adanya kesatuan jenis saja dalam melarang sebuah akad dalam riba nasiah. Penerapan prinsip ini dalam Ijärah adalah bahwa akad ini menurut mereka terjadi secara sedikit demi sedikit sesuai dengan terjadinya manfaat, maka manfaat pada waktu akad itu tidak ada (seutuhnya), sehingga salah satu pihak menjadi terlambat dalam menerima manfaat secara seutuhnya, maka terjadilah riba nasiah. Menurut Madhhab Syafi'iyah, kesamaan jenis saja tidak dapat mengharamkan akad dengan alasan riba, maka akad ini boleh menurut mereka dan tidak disyaratkan syarat ini. $^{34}$

Sedangkan menurut Taqiyyudin al-Nabhani memberikan kriteria sebagai berikut: ${ }^{35}$

a. Upah hendaklah jelas dengan bukti dan ciri yang bisa menghilangkan ketidakjelasan dan disebutkan besar dan bentuk upah.

b. Upah harus dibayarkan sesegera mungkin atau sesuai dengan waktu yang telah ditentukan dalam akad.

c. Upah tersebut bisa dimanfaatkan oleh pekerja untuk memenuhi kebutuhan kehidupannya dan keluarganya (baik dalam bentuk uang atau barang atau jasa).

d. Upah yang diberikan harus sesuai dan berharga. Maksud dari sesuai adalah sesuai dengan kesepakatan bersama, tidak dikurangi dan tidak ditambahi. Upah harus sesuai dengan pekerjaan yang telah dikerjakan, tidaklah tepat jika pekerjaan yang diberikan banyak dan beraneka ragam jenisnya, sedangkan upah yang diberikan tidak seimbang. Sedangkan berharga maksudnya adalah upah tersebut dapat diukur dengan uang.

e. Upah yang diberikan majikan bisa dipastikan kehalalannya, artinya barang-barang tersebut bukanlah barang curian, rampasan, penipuan atau sejenisnya.

f. Barang pengganti upah yang diberikan tidak cacat, misalnya barang pengganti tersebut adalah nasi dan lauk pauk, maka

\footnotetext{
${ }^{34}$ Ibid, 404.

${ }^{35}$ Taqyuddin al-Nabhani, Membangun Sistem Ekonomi Alternatif Perspektif Islam, (Surabaya: Risalah Gusti, 1996), 103-104.
} 
tidak boleh diberikan yang sudah basi atau berbau kurang sedap. $^{36}$

\section{Urgensi Pemberian Upah terhadap Pengajar Ilmu Agama}

Menurut UU No 13 tahun 2003 tentang ketenagakerjaan, kelayakan ekonomi ialah standar kebutuhan yang harus dipenuhi oleh seorang pekerja/buruh lajang untuk dapat hidup layak, baik secara fisik, non fisik dan sosial, untuk kebutuhan satu bulan. Dilihat dari segi intensitas kepentingannya, kebutuhan-kebutuhan manusia itu dibagi atas: kebutuhan primer, kebutuhan sekunder, dan kebutuhan tersier. Dari definisi tersebut dapat disimpulkan bahwa kelayakan ekonomi ialah kehidupan dimana seseorang merasa tercukupi secara finansial yang sangat erat kaitannya dengan pemenuhan kebutuhan pokok manusia dalam jangka waktu satu bulan. Begitu pula seorang guru dikatakan layak ekonominya apabila honor (penghasilan) yang diterimanya mampu mencukupi kebutuhan dirinya dan keluarganya dalam waktu satu bulan. Kebutuhan tersebut meliputi makanan dan minuman, pakaian, perumahan, pendidikan, kesehatan, transportasi, rekreasi, dan tabungan. ${ }^{37}$

Dalam Islam sudah dijelaskan meskipun tidak secara langsung tentang pentingnya memberi upah seseorang yang masih harus memenuhi kebutuhan hidupnya, sebagaimana dinyatakan dalam QS. al-Ṭalāq [65] : 6).

Artinya: "Jika mereka menyusukan (anak-anak)mu untukmu, maka berikanlah kepada mereka upahnya, dan musyawarahkanlah di antara kamu (segala sesuatu) dengan baik, dan jika kamu menemui kesulitan, maka perempuan lain boleh menyusukan (anak itu) untuknya."(QS. al-Ṭalāq [65] : 6). ${ }^{38}$

Dalam tafsir al-Nür ayat ini memberikan pengertian bahwa hak memberi air susu ibu dan anak dipikul oleh ayah, oleh karena itu janganlah para ayah terlalu sedikit memberikan biaya untuk si ibu

\footnotetext{
${ }^{36}$ Ibid, 104.

${ }^{37}$ Auliya Chandra Kirana, "Pengaruh Kelayakan Ekonomi Guru Terhadap Etos Kerja Di RA. Ath-Thohiriyyh Getas Jaten Karanganyar". (Naskah PublikasiFAIUM, Surakarta, 2014), 6-7.

38 Kemenag RI, Qur'an Asy-syifaa' Hafalan dan Tajwid Berwarna, (Bandung: Sygma Creative Media, 2018), 559.
} 
dan anaknya. ${ }^{39}$ Dari tafsir tersebut memberi isyarat dalam pengupahan jika pekerjaan si ayah hanyalah menjadi pengajar ilmu agama untuk memenuhi kewajiban sebagaimana seorang ayah.

Di Indonesia pada umumnya pengajar al-Qur'an seperti: guru TPA, guru agama, pengajar les privat mengaji, dan muballigh. Mereka mendapatkan materi dari pihak yang diajari al-Qur'an tersebut meskipun tidak secara langsung. Bagaimana Islam memandang penggajian terhadap pengajar ilmu agama yang berniat dakwah. Mengenai hal ini ada dua pandangan:

1. Mengajar agama adalah satu kewajiban dari orang yang mengetahui terhadap orang tidak mengetahui.

2. Mengajar ilmu agama harus dipandang sebagai aktifitas manusia yang perlu diberi imbalan sesuai dengan prestasi pengajar.

Jumhur ulama fiqh mendefinisikan ijärah adalah menjual manfaat yang boleh disewakan manfaatnya, bukan bendanya. ${ }^{40}$ Adapun Ibnu Hamzah mengatakan, pengambilan upah sebagai imbalan pengajaran al-Qur'an dan ilmu agama itu boleh, baik bulanan maupun sekaligus karena nas yang melarang tidak ada. ${ }^{41}$ Hail ini diperkuat juga dengan hadith nabi berikut:

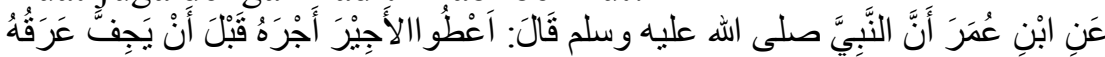
Dari Abdullah Ibn Umar berkata: Rasulullah $S A W$ bersabda: "Berikanlah upah kepada orang yang kamu pakai tenaganya sebelum kering keringatnya"(HR. Ibnu Majah, 2: 817). ${ }^{42}$

Dalam Fiqh Sunnah yang ditulis oleh Sayyid Sabiq, menerangkan bahwa generasi belakangan bisa mengekspresikan untuk pengajaran al-Quran dan ilmu-ilmu syariah, bahwa para Fuqaha' menfatwakan kebolehan mengambil upah ini sebagai perbuatan baik, setelah hubungan-hubungan dan pemberianpemberian yang dahulu biasa mengalir kepada mereka, yang menjadi guru dari orang kaya dan Baitul Māl pada masa-masa awal, hal ini dimaksudkan untuk menghindari kesusahan dan kesulitan, karena

39 Teungku Muhammad Hasbi aș-Șiddiqi, Tafsir al-Qur'anul Majid an-Nūr, (Jakarta: Cakrawala Publishing, 2011), 364.

${ }^{40}$ Rahmat Syafi'e, Fiqh Muamalah, (Bandung: Putaka Setia, 2000), 122.

${ }^{41}$ Hendi Suhendi, Fiqh Muamalah, (Jakarta: PT Grafindo Persada, 2005), 120.

42 Ibnu Majah, Sunan Ibnu Majah, Jil. 2, Ed., Muhammad Nashiruddin al-Albani, (Jakarta: Pustaka Azzam, 2007), 303. 
mereka (para guru) membutuhkan penunjang kehidupan mereka dan kehidupan orang yang berada dalam tanggungan mereka.

Dalam mengajar ilmu agama Islam dan al-Qur'an membutuhkan waktu yang cukup, agar benar- benar memahaminya secara keseluruhan, karena tanggung jawab yang besar, karena alQuran sebagai pembeda antara yang hak dan yang batil. Guna menggiring umat ke jalan yang benar, juga untuk mengumpulkan beberapa orang untuk diberi pelajaran, atau paling tidak, tidak menyembunyikan ilmu. Terutama mengenai agama yang berasal dari sunnah yang diancam Allah SWT. dengan adzab-Nya.

Salah satu akibatnya dari hal-hal tersebut kadang menyita banyak waktu. Kata pepatah "waktu adalah uang" begitu pula hal-hal tersebut memakan waktu yang lama, kadang pengabdian tersebut memakan waktu yang tidak sebentar, kadang pengabdian tersebut hampir seluruh waktunya tersita dalam satu hari. Dalam sehari, pekerja bisa saja mendapatkan upah sebesar 50.000,- bagaimana jika sebulan, setahun, dan seterusnya. ${ }^{43}$ Maka dari itu, sangatlah penting dalam mensejahterakan pengajar ilmu agama dengan pengupahan yang layak.

\section{Hukum Menerima Upah Bagi Pengajar Ilmu Agama}

Tentang pengambilan upah dari mengajarkan al-Qur'an, para ulama fikih juga berselisih pendapat dalam masalah ini. Sekelompok Fuqaha' tidak memperbolehkan, sedang sekelompok lainnya membolehkannya.

1. Ulama Yang Tidak Memperbolehkan.

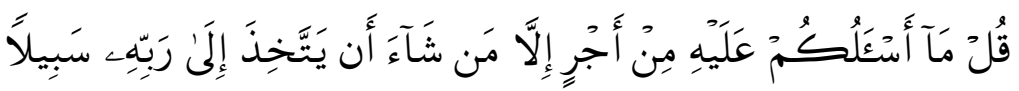

Artinya: "Katakanlah: "Aku tidak meminta upah sedikitpun kepada kamu dalam menyampaikan risalah itu, melainkan (mengharapkan kepatuhan) orang-orang yang mau mengambil jalan kepada Tuhan nya."(QS. al-Furqān [25]: 57)

Berangkat dari ayat tersebut di atas, Rasulullah saw., diperintahkan dan diperingatkan oleh Allah swt., berkali-kali dalam

${ }^{43}$ Arif Isnaini, "Profesi Keagamaan dalam Persepektif Hukum Islam" (SkripsiUIN Sunan Kalijaga, Surabaya, 2009), 6-7.

${ }^{44}$ Kemenag RI, Qur'an Asy-syifaa' Hafalan dan Tajwid Berwarna, (Bandung: Sygma Creative Media, 2018), 365. 
al-Qur'an bahwa beliau tidak diperkenankan mengambil upah dari dakwahnya mengajak umat dengan alasan apapun. Ayat ini juga menerangkan tentang firman Allah swt., kepada nabi Muhammad SAW. untuk tidak mengambil upah atas perbuatan dakwah, kecuali jika atas kerelaan seseorang untuk menginfakkan hartanya di jalan Allah, dan bersedekah sebagai bentuk taqarrub kepada Allah, dan membiayai jihad melawan musuh, dan untuk jalan kebaikan lainnya. ${ }^{45}$ Senada dengan ayat ini, Allah berfirman:

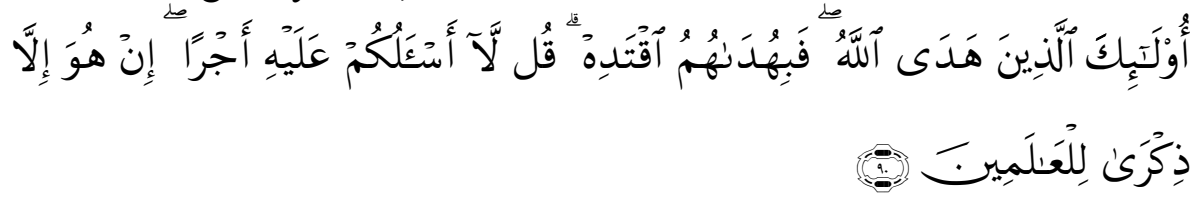

Artinya: "Mereka itulah orang-orang yang telah diberi petunjuk oleh Allah, maka ikutilah petunjuk mereka. Katakanlah: "Aku tidak meminta upah kepadamu dalam menyampaikan (al-Quran). " al-Quran itu tidak lain hanyalah peringatan untuk seluruh umat." (QS. alAn'àm [6]: 90). ${ }^{46}$

Dalam tafsir al-Tabari terhadap ayat di atas, Abū Ja'far menyatakan bahwa Allah swt., mengingatkan kepada nabi Muhammad saw., agar mengatakan kepada orang-orang musyrik bahwa atas peringatan yang diberikan kepada mereka, atas petunjuk yang ia dakwahkan kepada mereka, dan atas al-Qur'an yang dibawanya untuk mereka, ia tidak akan meminta upah sebagai balasannya. $^{47}$

Ulama-ulama klasik dari kalangan Madzhab Hanafî berpendapat bahwa mengambil upah dari murid atas pengajaran alQuran dan ilmu lainnya tidak diperbolehkan. Ini sesuai dengan sabda Nabi saw., yang diriwayatkan Imam Ahmad dalam musnadnya bahwa beliau saw., melarang mengambil upah dari al-Qur'an.

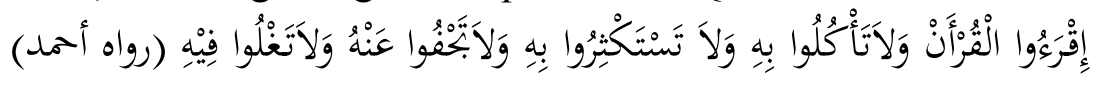

${ }^{45}$ Muhammad Ibn Jarir al-Ṭabarì, Jāmi' al-Bayān fỉ Ta'wìl al-Qur'ān, Vol. 12 (Beirūt: Mu'assasah al-Risalah, 2000 ), 357.

${ }^{46}$ Kemenag RI, Qur'an Asy-syifaa' Hafalan dan Tajwid Berwarna, (Bandung: Sygma Creative Media, 2018), 138.

${ }^{47}$ Muhammad Ibn Jarìr al-Ṭabarì, Jāmi' al-Bayān fỉ Ta'wìl al-Qur'ān, Vol. 15 (Beirut: Mu'assasah al-Risalah, 2000), 520. 
'Bacalah al-Qur'an dan janganlah kalian makan dari itu, dan jangan juga kalian memperbanyak kekayaan dari itu."(HR Imam Ahmad) ${ }^{48}$

"Dari Ubai bin Ka'ab pernah berkata: "Aku pernah mengajarkan alQur'an kepada seseorang, kemudian aku diberikan sebuah busur (panah). Lalu aku kabarkan kepada nabi Muhammad saw, lalu beliau berkata: jika kau mengambilnya, itu berarti kau telah mengambil sebuah busur neraka, lalu aku kembalikan busur itu."

Nabi Muhammad saw., adalah muballigh ulung, master dari semua muballigh yang ada di dunia ini, dan Beliau saw., tidak mengambil upah atas dakwahnya itu. Maka seorang dai juga tidak boleh mengambil upah atas dakwahnya sebagaimana Nabi saw., tidak mengambil upah dari sebuah dakwah atau pengajaran al-Qur'an dan ilmu lainnya justru membuat orang enggan untuk belajar, karena besarnya biaya yang harus dibayar.

Allah swt., telah mengisyaratkan kita tentang hal ini dalam Q.S. al-Qalam [67] : 46) "Apakah kamu meminta upah kepada mereka, lalu mereka diberati dengan hutang?"50

Demikian halnya dengan seorang ustadh, guru agama, dosendosen yang mengajarkan ilmu-ilmu agama atau para dai atau khatib yang menyampaikan ceramah-ceramahnya, maka tidak dibolehkan bagi mereka menerima upah dari pengajarannya itu sebagaimana tidak dibolehkannya seorang yang mengajarkan al-Qur'an dengan mengambil upah atau bayaran atau gaji dari pengajaran al-Qur'annya kepada murid-muridnya. Diriwayatkan oleh Bukhari dan Muslim dari Umar bin Khattab dia berkata, "Rasulullah SAW bersabda: "Sesungguhnya amalan itu tergantung dengan niatnya, dan sesungguhnya ia akan mendapatkan sesuatu yang diniatkan. ${ }^{.51}$

Dinyatakan dalam firman Allah yang artinya: "Katakanlah (hai Muhammad): "Aku tidak meminta upah sedikitpun padamu atas dakwahku dan bukanlah aku termasuk orang-orang yang mengada-

48 Ibnu Majah, Sunan Ibnu Majah, Jil. 2, Ed., Muhammad Nașiruddin al-Albānī, (Jakarta: Pustaka Azzam, 2007), 303.

49 Abu Bakar Muhammad, Terjemahan Subulus Salam, (Surabaya: al-Ikhlas, 1991), 291.

50 Kemenag RI, Qur'an Asy-syifaa' Hafalan dan Tajwid Berwarna, (Bandung: Sygma Creative Media, 2018), 566.

${ }^{51}$ Imam Nawawi, al-Arba'in an-Nawawiyah, (Mesir: Markaz Fajr Kairo, 1250), 3. 
adakan." (QS. Shād [38] : 86). ${ }^{52}$ Berkenaan dengan ayat di atas, di dalam tafsir al-Tabari jilid xxi halaman 243 dikemukakan bahwa penulisnya menerima hadith dari Yunus yang berkata: "Ibn Wahb mengkhabarkan kepadaku; katanya 'berkata Ibn Zaid: firman Allah tersebut tafsirnya adalah aku tidak akan meminta upah dalam bentuk apapun pada kalian atas al-Qur'an, dan aku tidak akan membebankan sesuatu yang tidak diperintahkan Allah kepadaku."

Penjelasan di atas dapat disimpulkan bahwasanya seorang yang mengajar ilmu agama seperti mengajar al-Qur'an, ilmu Fiqh, hadith ataupun yang lainnya itu tidak diperbolehkan. Dan para ulama yang berpendapat demikian, semua merujuk terhadap ayat al-Qur'an dan hadith tertentu yang disesuaikan dengan kemampuan ijtihad mereka masing-masing.

\section{Ulama Yang Memperbolehkan}

Menerima upah dalam mengajarkan al-Qur'an pada saat ini sudah dianggap wajar, karena selama ini relatif tidak ada keluhan dari masyarakat. Apalagi alam globalisasi menuntut masyarakat untuk bersikap profesional dan menghargai profesionalisme itu sendiri.

Hal itu sesuai dengan yang dikatakan al-Wadi' bin 'Ata' beliau berkata: "Ada tiga orang guru yang mengajarkan al-Qur'an kepada anak-anak Madinah. Umar pun memberi gaji kepada mereka lima belas dirham setiap bulan."

Dalam kitab suci al-Qur'an; tidak terdapat ayat yang menyatakan melarang perbuatan mengambil upah mengajarkan alQur'an. ${ }^{53}$ Ayat-ayat mengenai hal tersebut adalah dinyatakan dalam QS. al-Qașas [28] : 27)

Artinya: "Berkatalah Dia (Shu'aib): "Sesungguhnya aku bermaksud menikahkan kamu dengan salah seorang dari kedua anakku ini, atas dasar bahwa kamu bekerja denganku delapan tahun, dan jika kamu cukupkan sepuluh tahun maka itu adalah (suatu kebaikan) dari kamu, maka aku tidak ingin memberatkan

52 Kemenag RI, Qur'an Asy-syifaa' Hafalan dan Tajwid Berwarna, (Bandung: Sygma Creative Media, 2018), 458.

${ }^{53}$ Umar Shahab, “Al-Ujrah 'Alā al-Ṭā'ah; Suatu Tinjauan Syar'i dan Sosiologis Terhadap Kegiatan Dakwah Dewasa ini”, dalam Chuzaimah T. Yanggo dan Hafizh Anshari, Problematika Hukum Islam Kontemporer. Cet 1, (Jakarta: Pustaka Firdaus, 1995), 130. 
kamu. dan kamu insya Allah akan mendapatiku termasuk orang- orang yang baik". ${ }^{54}$

Ayat tersebut bertutur tentang ayah dua wanita yang dibantu oleh Nabi Musa as., mengambilkan air minum untuk ternaknya, yang menyatakan bahwa ia hendak menikahkan nabi Musa as., dengan salah satu putrinya dengan mahar berupa pekerjaan mengembalakan ternaknya selama delapan tahun. Artinya upah dari mengembalakan ternak selama delapan tahun menjadi maharnya. ${ }^{55}$ Sedangkan hadith mengenai diperbolehkannya memberi upah dalam mengajari alQur'an adalah sebagai berikut:

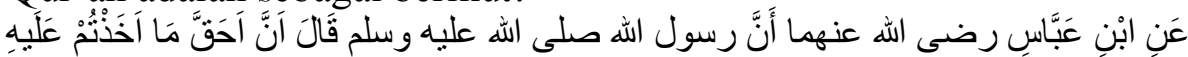

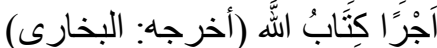

Artinya: "Dari Ibnu Abbas r.a. (katanya) sesungguhnya suatu peekerjaan yang paling berhak kamu ambil upahnya ialah (mengajarkan) Kitabullah (al-Qur'an). Diriwayatkan oleh alBukhari." 56

Pendapat Madzhab Hambali dan Ibnu Taimiyah, bahwa diperbolehkannya mengajar al-Qur'an dan mengambil upah darinya jika membutuhkannya. Mereka yang membolehkannya menganggap perbuatan mengajar al-Qur'an sama dengan perbuatan-perbuatan lainnya. Di samping itu, mereka juga mengemukakan alasan dengan sebuah hadith yang diriwayatkan dari Abū Sa'id al-Khudri ra: ${ }^{57}$

Artinya: "Sesungguhnya para sahabat Rasulullah saw., berada pada salah satu peperangan, kemudian mereka melewati salah satu kampung Arab. Lalu mereka (orang kampung) berkata, "Apakah ada tukang jampi-jampi pada kamu? Sesungguhnya kepala kampung telah disengat atau tertimpa sesuatu”. Abu Sa'id berkata, "Maka salah seorang (diantara mereka) membacakan doa dengan surat al-Fätihah, maka sembuhlah ia. Kemudian kepala kampung itu memberi sekelompok kambing, namun sahabat tersebut enggan menerimanya. Lalu ia menanyakan hal itu kepada Rasulullah saw., beliau bertanya,

54 Kemenag RI, Qur'an Asy-syifaa' Hafalan dan Tajwid Berwarna, (Bandung: Sygma Creative Media, 2018), 388.

${ }^{55}$ Muhammad Ibn Jarìr al-Ṭabarì, Jāmi' al-Bayān fî̀ Ta'wỉl al-Qur'ān, Vol. 19, (Beirut: Mu'assasah ar-Risalah, 2000), 565.

${ }^{56}$ Abu Bakar Muhammad, Terjemahan Subulus Salam, (Surabaya: al-Ikhlas, 1991), 290.

${ }^{57}$ Ibid, 205. 
Menakar Pro-Kontra Hukum Ujrah Pengajar Ilmu Agama

"Dengan apakah kamu menjampi-jampinya?" sahabat menjawab, "Dengan surat al-Fätihah", beliau berkata lagi, "Tidak tahukah kamu bahwa itu adalah jampi-jampi?" Abu Sa'id berkata: kemudian Rasulullah $S A W$. bersabda, "Ambillah itu, dan berikan sebagian daripadanya untukku bersama kamu". 58

\section{Epilog}

Berdasarkan paparan data di atas, maka dapat disimpulkan bahwa dalam pembahasan ini tidak ada dalil al-Qur'an yang langsung memperbolehkan upah, hanya saja, ada ayat yang menyinggung terhadap hal tersebut. Sedangkan jika ditinjau dari hadith di atas sudah sangat jelas bahwa upah tersebut diperbolehkan bahkan dianjurkan.

\section{Dartar Pustaka}

Ahmad, Nazih. Qaḍāyā Fiqhiyyah Mu'āsirah fī al-Māl wa al-Iqtị̦ād, Damaskus: Dar al-Qalam. 2001.

Antonio, Muhammad Syafii. Bank Syariah dari Teori ke Praktik, Jakarta: Gema Insani, 2001.

Askhabi, Moh Aqim. "Pemberian Imbalan dalam Aktifitas Dakwah Agama Islam", Journal Fisip Unair, vol. 4, No. 2, (Februari, 2015).

Arskal Salim, Etika Intervensi Negara: Perspektif Etika Politik Ibnu Taimiyah, Jakarta: Logos, 1999.

Azzubaidi, Zaenuddin Ahmad. Terjemah Hadits Shahih Bukhari, Terj, Muhammad Zuhri, Semarang: CV. Toha Putra, 1986.

'Assal, Ahmad Muhammad al- dan Fathi Ahmad Abdul Karim. Sistem, Prinsip dan Tujuan Ekonomi Islam, Terj, Imam Saefudin, (Bandung: CV Pustaka Setia, 1999).

Chamberlain, Michael. "Knowledge and Social Practice In "Medieval Damascus,", Dinamika, Vol. 15, No. 1, (Juli 2015).

Dahlan, Abdul Aziz DKK. Ensiklopedi Tematis Dunia Islam Ajaran, Jakarta, PT Ichtiar Baru Van Hoeve, tt.

Faifi, Syaikh Sulaiman Ahmad Yahya al-. Ringkasan Fikih Sunnah Sayyid Sabiq, Terj, Ahmad Tirmidzi dkk, Jakarta: Pustaka alKautsar, 2014.

${ }^{58}$ Ibid, 206. 
Ghazali, Imam Al- Ihya'. Ulumuddin Hak Milik Muslim, Selangor: Illusion Network, 2013.

Habieb, Sa'di Abu. Ensiklopedi Ijmak Persepakatan Ulama' dalam Hukum Islam, Terj, Sahul Machfudz dan Mustofa Bisri, Jakarta: Pustaka Firdaus, 1987.

Husaini, Imam Taqiyuddin Abu Bakar al-. Terjemahan Kifayatul Akhyar, Jil. II, Terj, Achmad Zainuddin dan A. Ma'ruf Asrori, Surabaya: PT Bina Ilmu, 2011.

Ibnu Majah, Sunan Ibnu Majah, Jil. II, Terj, Muhammad Nashiruddin al-Albani, Jakarta: Pustaka Azzam, 2007.

Isnaini, Arif "Profesi Keagamaan dalam Persepektif Hukum Islam" Skripsi-UIN Sunan Kalijaga, Surabaya, 2009.

Jabirah bin Ahmad al-Harithi, Fikih Ekonomi Umar bin al-Khatab, Terj, Asmuni Solihin Zamakhsyari, (Jakarta: Pustaka alKautsar, 2014.

Jalaluddin al-Mahalli dan Jalaluddin al-Suyuṭī, Tafsir al-Qur'an alAzīm li Imām al-Jalālain, (t.t.: cv. Pustaka, t.th).

Karim, Helmi Fiqih Muamalah, Jakarta: Salemba Empat, 2001.

Kemenag RI, Qur'an Asy-syifaa' Hafalan dan Tajwid Berwarna, Bandung: Sygma Creative Media, 2018.

Kirana, Auliya Chandra "Pengaruh Kelayakan Ekonomi Guru Terhadap Etos Kerja Di RA. Ath-Thohiriyyh Getas Jaten Karanganyar". (Naskah Publikasi-FAIUM, Surakarta, 2014.

Lubis, Suhrawardi K. dan Farid Wajdi. Hukum Ekonomi Islam, (Jakarta: Sinar Grafika, 2012.

Majah, Ibnu. Sunan Ibnu Majah, Jil. 2, Ed., Muhammad Nashiruddin al-Albani, (Jakarta: Pustaka Azzam, 2007.

Muhammad, Abu Bakar. Terjemahan Subulus Salam, Surabaya: alIkhlas, 1991.

M. Abdul Mannan, Teori dan Praktek Ekonomi Islam, Yogyakarta: PT. Dana Bhakti Prima Yasa, 1997.

Moekijat, Administrasi Gaji Dan Upah , Bandung: Mandar Maju, 1992.

Muhammad Syafii Antonio, Bank Syariah dari Teori ke Praktik, (Jakarta: Gema Insani Pers, 2001.

Muhammad, Abu Bakar. Terjemahan Subulus Salam, (Surabaya: alIkhlas, 1991), 290.

Munawwir, Ahmad. Warson Kamus Al-Munawwir, (Surabaya: Penerbit Pustaka Progresif, 1997). 
Nabhani, Taqyuddin al-. Membangun Sistem Ekonomi Alternatif Perspektif Islam, (Surabaya: Risalah Gusti, 1996.

Nawawi, Imam. al-Arba'in an-Nawawiyah, Mesir: Markaz Fajr Kairo, 1250.

Orgianus, Yan. Moralitas Islam dalam Ekonomi dan Bisnis, Bandung: Penerbit Marja, 2012.

Qomarul Huda, Fiqh Muamalah, (Yogyakarta: Sukses Offset, 2011.

Riyadi, Fuad. "Sistem Dan Strategi Pengupahan Perspektif Islam", Jurnal Iqtishadia, Vol. 8, No. 1, (Maret, 2015).

Sabiq, Sayyid. Fiqh al-Sunnah, Terj, Nor Hasanudin, (Jakarta: Pena Pundi Aksara, 2006).

Shahab, Umar. "Al-Ujrah 'Alā al-Tăa'ah; Suatu Tinjauan Syar'i dan Sosiologis Terhadap Kegiatan Dakwah Dewasa ini”, dalam Chuzaimah T. Yanggo dan Hafizh Anshari, Problematika Hukum Islam Kontemporer. Cet 1, Jakarta: Pustaka Firdaus, 1995.

Șiddiqi, Teungku Muhammad Hasbi aș-. Tafsir al-Qur'anul Majid anNür, Jakarta: Cakrawala Publishing, 2011.

Sholahuddin, Muhammad. Kamus Istilah Ekonomi, Keuangan, dan Bisnis Syariah $A-Z$, Jakarta: PT Gramedia Pustaka Utama, 2011.

Suhendi, Hendi. Fiqh Muamalah, (Jakarta: PT Grafindo Persada, 2005.

Suhrawardi K. Lubis dan Farid Wajdi, Hukum Ekonomi Islam, Jakarta: Sinar Grafika, 2012.

Syafi'e, Rahmat. Fiqh Muamalah, Bandung: Putaka Setia, 2000.

Taqyuddin an-Nabhani, Membangun Sistem Ekonomi Alternatif Perspektif Islam, (Surabaya: Risalah Gusti, 1996.

Ṭabarī, Muhammad Ibn Jarir al-. Jāmi' al-Bayān fì Ta'wìl al-Qur'ān, Vol. 12, Beirūt: Mu'assasah al-Risalah, 2000.

Zuhaili, Wahbah al-. Fiqih Islam Wa Adillatuhu, Terj, Abdul Hayyie al-Kattani, dkk, Depok: Gema Insani, 2011. 